\title{
Endocytosis at the basal and lateral membranes of rat uterine epithelial cells during early pregnancy
}

\author{
Margaret B. Parr* \\ Department of Anatomy and Histology, University of Adelaide, Adelaide, Australia 5001
}

\begin{abstract}
Summary. By 20 min after intravenous injection of horseradish peroxidase on Day 5 of pregnancy the tracer was present between the lateral epithelial cell membranes, in coated and non-coated invaginations in the lateral and basal membranes of epithelial cells, and in pinocytotic vesicles at the periphery of epithelial cells. By 60 min after injection the tracer was also distributed in vesicles throughout the epithelial cell cytoplasm. By $2 \mathrm{~h}$ the tracer was present only in a few vesicles in the apical region of epithelial cells, and some of these vesicles appeared to be fusing with the apical cell membrane. Pinocytotic invaginations in the basal membrane of uterine epithelial cells were 4-5-fold more numerous on Day 5 of pregnancy than on Days 1-4 and 7, suggesting a specific role for this activity during early pregnancy. The observations show that uterine epithelial cells can pinocytose substances derived from blood, transport them to the apical cytoplasm, and possibly release them into the uterine lumen by exocytosis.
\end{abstract}

\section{Introduction}

Endocytosis appears to be one of the major activities of the uterine epithelium of rats and mice before implantation and is under the control of ovarian hormones (Vokaer, 1952; Enders \& Nelson, 1973; Parr \& Parr, 1974, 1977; Leroy, Van Hoeck \& Bogaert, 1976). Markers, such as ferritin, injected into the uterine lumen are taken up by the cells into $0.5-3.0 \mu \mathrm{m}$ endocytotic or pinopodial vacuoles and into $0.1 \mu \mathrm{m}$ coated pinocytotic vesicles. Both types of ferritincontaining vesicles are then channelled into lysosomes. Endocytosis occurs on Days 4-6 of pregnancy, with a distinct peak of activity on Day 5 when blastocysts are present in the uterine lumen (Parr \& Parr, 1978). The biological role of endocytosis in the preimplantation period remains unknown, although many functions have been suggested (Enders \& Nelson, 1973; Parr \& Parr, 1974; Leroy et al., 1976).

Although there is active endocytosis at the apical surface of epithelial cells during the preimplantation period, little is known about pinocytotic activity at non-apical surfaces. Horseradish peroxidase injected intravenously into immature rats treated with oestradiol-17 was located in pinocytotic vesicles in the basal and lateral membranes, in cisternae of the endoplasmic reticulum and in apical vesicles (Anderson, Kang \& De Sombre, 1975). Anderson et al. (1975) suggested that the tracer could be transported into the lumen by an intracellular route. In ovariectomized rats treated with progesterone, Ljungkvist (1971) observed coated vesicles and invaginations at the basal membranes of luminal epithelial cells. He suggested that they may transport substances derived from the stroma and/or blood vessels, but since only a small number was observed it seemed unlikely that this transport was significant. The purpose of

Present address: Unit of Human Morphology, School of Medicine, The Flinders University of South Australia, Bedford Park, Australia 5042. 
the present investigation was to study the pinocytotic activity at the basal and lateral membranes of uterine epithelial cells during early pregnancy by following the uptake and intracellular fate of intravenously injected horseradish peroxidase.

\section{Materials and Methods}

Virgin female albino rats $60-100$ days old and weighing $180-280 \mathrm{~g}$ were obtained from the Adelaide University Central Animal House. The rats were mated and the day on which spermatozoa were found in the vaginal smears was designated Day 1 of pregnancy.

\section{Electron microscopy}

On Days 1-7 of pregnancy 27 rats were anaesthetized with tribromoethanol and their uteri were fixed by vascular perfusion with a mixture of $2.5 \%$ glutaraldehyde (E.M. grade, TAAB

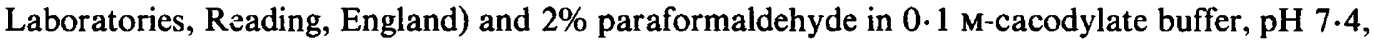
at room temperature. After perfusion for $30 \mathrm{~min}$, the uteri were removed, cut into small segments and immersion fixed for $1 \frac{1}{2} \mathrm{~h}$. The uterine tissue was washed in buffer overnight, post-fixed in a mixture of $1 \% \mathrm{OsO}_{4}$ and $1.5 \%$ potassium ferrocyanide in distilled water for $1 \mathrm{~h}$ at $4{ }^{\circ} \mathrm{C}$ (Karnovsky, 1971), washed, dehydrated, and embedded in Spurr's medium. The uteri were orientated so that transverse sections of uterine horns were cut. Sections $(0.5 \mu \mathrm{m})$ were stained with toluidine blue in borate buffer. Thin sections were stained with uranyl acetate and lead citrate and examined in a Philips EM-300 electron microscope. The number of basal pinocytotic invaginations in a sample of uterine epithelial cells from each rat was counted. In addition, the length of the basal membranes of epithelial cells was measured on micrographs $(\times 16400)$ of 30 cells from 6 rats on Days 4, 5 and 7 using a Panasonic map measure.

\section{PLATE 1}

Electron micrographs of rat uterine epithelial cells on Day 5 of pregnancy 20 min after intravenous injection of horseradish peroxidase.

Fig. 1. Peroxidase-reaction product below the basement membrane and in coated and non-coated pinocytotic invaginations in the basal membrane. $\times 35000$.

Fig. 2. Peroxidase-reaction product along the basal membrane, between the lateral membranes and in pinocytotic vesicles in the cytoplasm. $\times 35750$.

\section{PLATE 2}

Electron micrographs of rat uterine epithelial cells on Day 5 of pregnancy 60 min after intravenous injection of horseradish peroxidase.

Fig. 3. Peroxidase-reaction product in a tubular vesicle (V) in the apical cytoplasm. Note the electron-transparent irregular vesicles (AV) in the apical cytoplasm and microvilli (MV) extending into the uterine lumen $(L)$. Unstained section. $\times 67500$.

Fig. 4. Peroxidase-reaction product between the lateral membranes in a pinocytotic vesicle in the lateral membrane and in larger vesicles $(\mathrm{V})$ in the cytoplasm adjacent to the nucleus $(\mathrm{N})$. Unstained section. $\times 33600$.

\section{PLATE 3}

Fig. 5. Electron micrograph of rat uterine epithelial cell on Day 5 of pregnancy 120 min after intravenous injection of horseradish peroxidase, showing reaction product in vesicles in the apical cytoplasm. Note the proximity of the tubular vesicle and apical cell membrane, suggesting fusion of the two membranes. Reaction product is absent between the lateral membranes. Unstained section. $\times 61400$. 
PLATE I

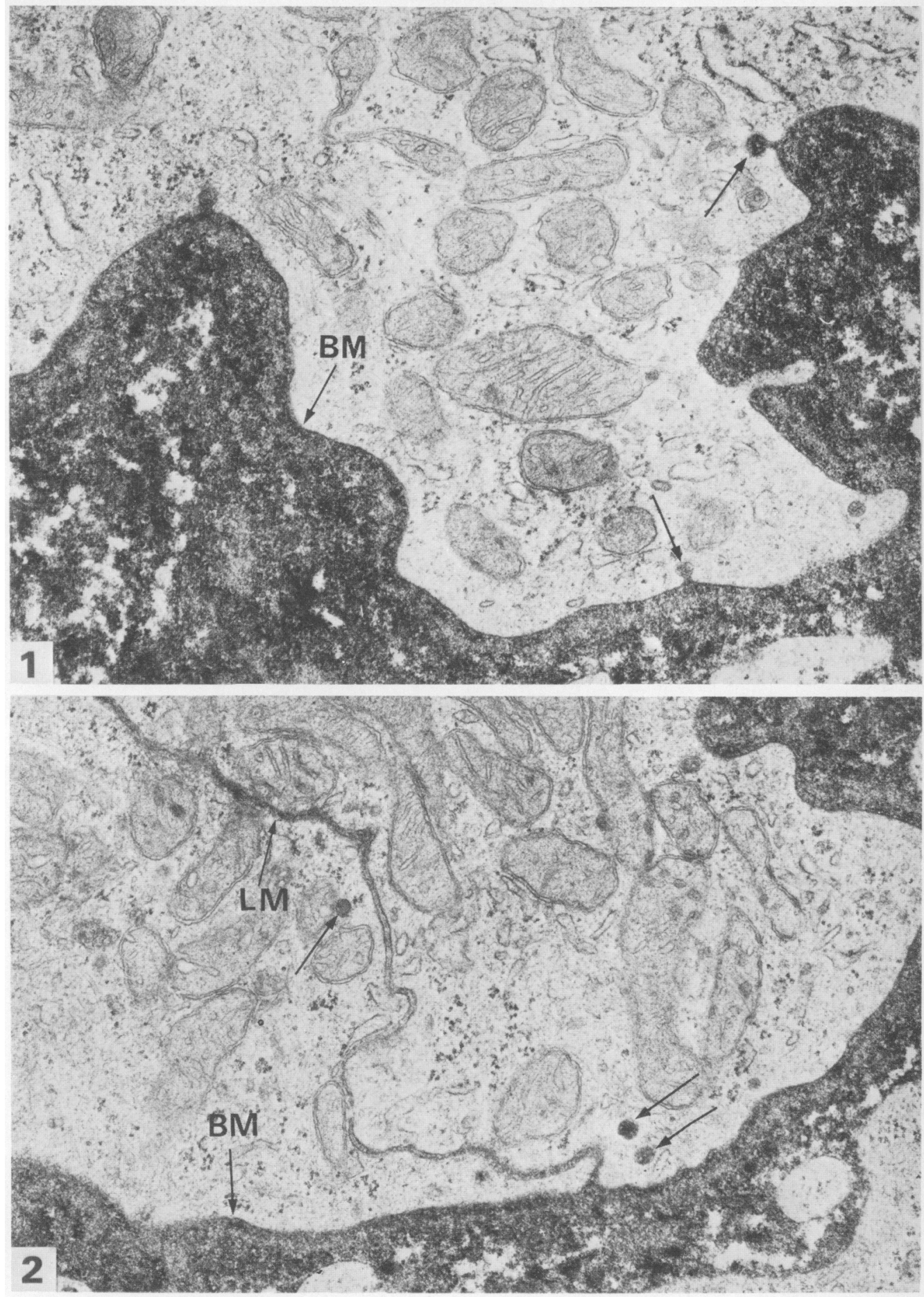

(Facing p. 96) 


\section{PLATE 2}

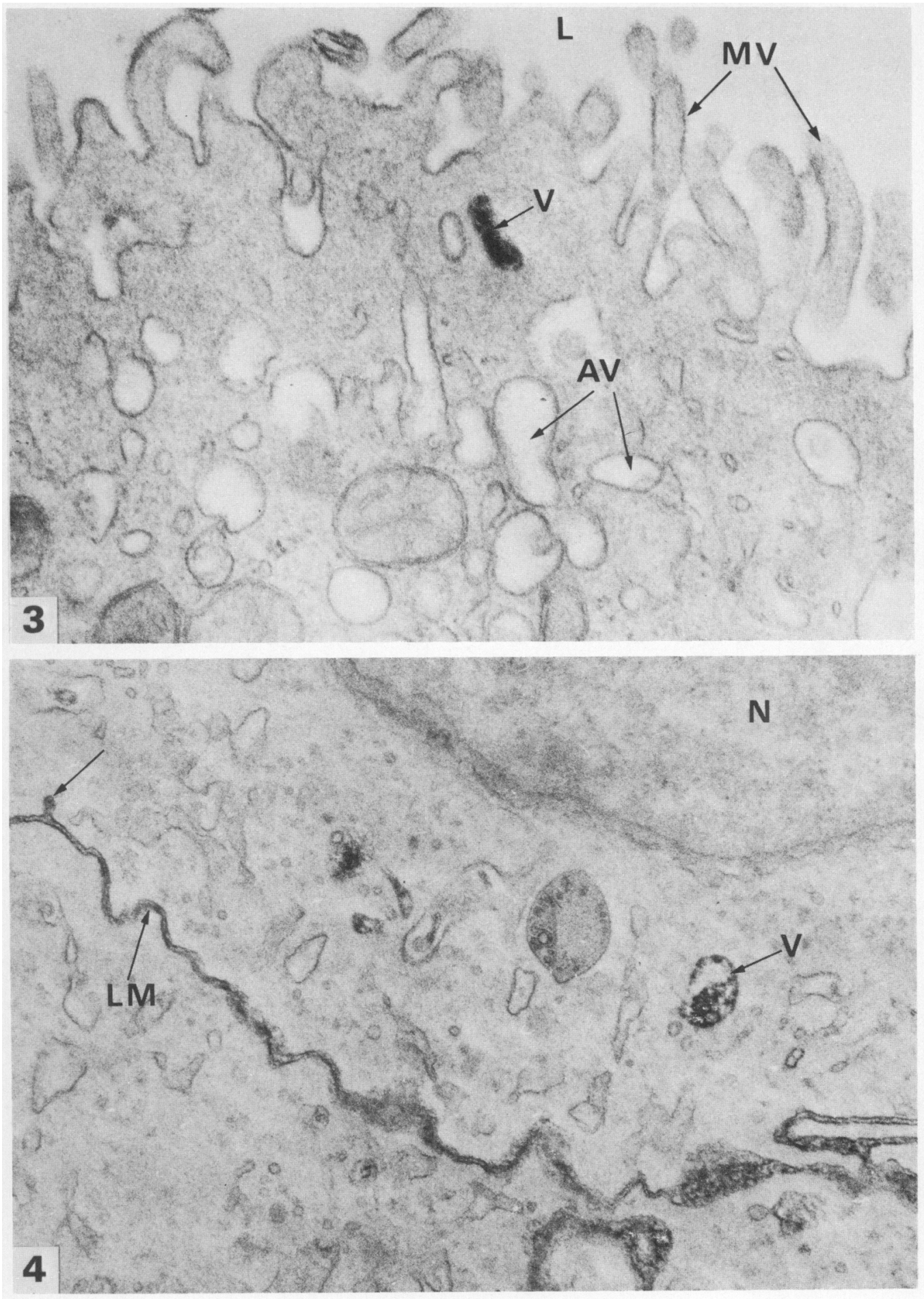




\section{PLATE 3}

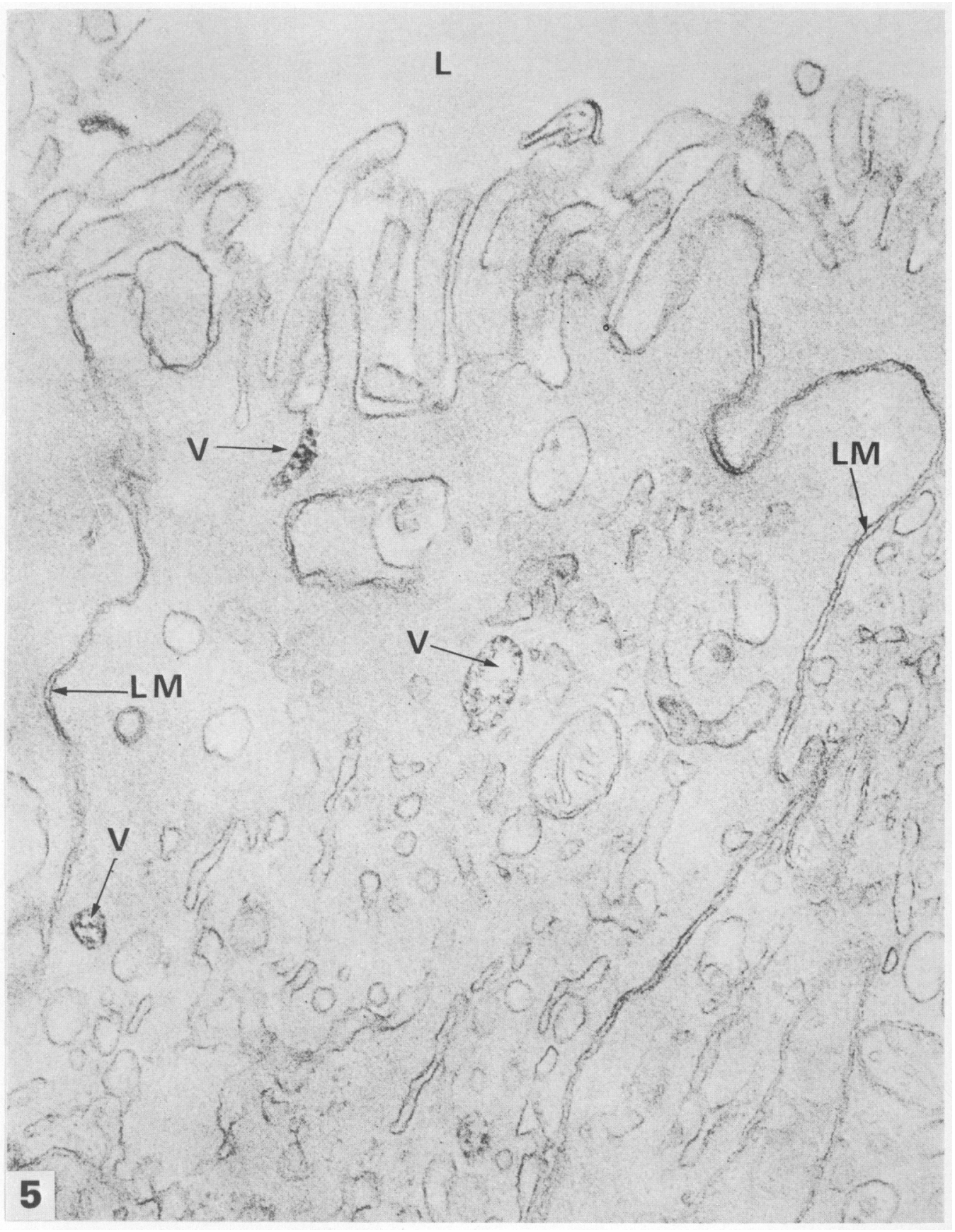




\section{Histochemistry}

On Day 5 of pregnancy, 12 rats were injected with horseradish peroxidase (Týpe II, Sigma Chemical Co., St Louis, Missouri) dissolved in isotonic saline $(0.154 \mathrm{M}-\mathrm{NaCl})$, at $10 \mathrm{mg} / 100 \mathrm{~g}$ body weight, into the saphenous vein. The rats were anaesthetized 20,60 or 120 min later and their uteri were fixed as described above using cold fixative. The uteri of 3 other rats not injected with horseradish peroxidase or saline were similarly treated. After the uterine tissues from both groups of rats were washed in buffer overnight, $40 \mu \mathrm{m}$ frozen sections were cut and horseradish peroxidase was demonstrated by the method of Graham \& Karnovsky (1966). Uterine sections from control and peroxidase-injected rats were also incubated in medium without hydrogen peroxide. The sections were washed, post-fixed and prepared for electron microscopy as described above. Thin sections were studied unstained or lightly stained.

\section{Results}

Rat uterine epithelial cells during early pregnancy exhibited coated and non-coated invaginations in the lateral and basal membranes (Pl. 1, Fig. 1; Pl. 2, Fig. 4). The average number of basal pits or invaginations per cell was highest on Days 5 and 6 (Table 1). This increase was not caused by an increase in the width of the cells because measurements of the mean ( \pm s.d.) length of the basal membranes on Days 4,5 and $7(7.9 \pm 2.7,7.1 \pm 3.7$ and $6.8 \pm 2.7 \mu \mathrm{m}$, respectively) showed no statistically significant differences.

Table 1. The number of basal pinocytotic invaginations in the rat uterine epithelium during early pregnancy

\begin{tabular}{cccc}
\hline $\begin{array}{c}\text { Day of } \\
\text { pregnancy }\end{array}$ & $\begin{array}{c}\text { No. of } \\
\text { rats }\end{array}$ & $\begin{array}{c}\text { No. of cells } \\
\text { examined }\end{array}$ & $\begin{array}{c}\text { Pinocytotic invaginations per cell } \\
\text { (mean } \pm \text { s.e.m.) }\end{array}$ \\
\hline 1 & 5 & 124 & $0.48 \pm 0.09$ \\
3 & 2 & 60 & $0.63 \pm 0.16$ \\
4 & 4 & 150 & $0.71 \pm 0.10$ \\
5 & 6 & 268 & $2.60 \pm 0.08^{*}$ \\
6 & 6 & 242 & $1.09 \pm 0.09^{*}$ \\
7 & 4 & 163 & $0.58 \pm 0.08$ \\
\hline
\end{tabular}

* Statistically significant compared with values obtained for Day 1 of pregnancy, $P<0.0005$ (Student's $t$ test).

The experiments using horseradish peroxidase as a tracer showed that the invaginations were pinocytotic. By $20 \mathrm{~min}$ after injection peroxidase reaction-product was localized between the stromal cells, along the basement membrane, between the lateral cell membranes up to the zonula occludens, in pinocytotic invaginations in the basal and lateral epithelial cell membranes, and in pinocytotic vesicles $(0.09 \mu \mathrm{m}$ maximum diameter) in the peripheral cytoplasm (Pl. 1, Figs 1 and 2). By $1 \mathrm{~h}$ after injection the peroxidase reaction product was found in all the above sites and in tubular and irregularly shaped vesicles throughout the cytoplasm, particularly in the apical regions ( $\mathrm{Pl}$. 2, Figs 3 and 4). At $2 \mathrm{~h}$ after treatment the tracer was no longer detected in the interstitium or between the lateral membranes of the epithelial cells but some pale reaction product could be detected in a few vesicles at the apex of some of the epithelial cells (Pl. 3, Fig. 5). Vesicles containing tracer were sometimes seen close to or in apparent contact with the apical membrane, suggesting fusion of the vesicles with the surface membrane (Pl. 33i.Fig. 5 ) $!$ 04/26/2023 12:16:05PM 


\section{Discussion}

Uterine epithelial cells exhibit two endocytotic pathways on Days 5 and 6 of pregnancy. Endocytotic vacuoles formed at the apical surface are channelled into lysosomes (Parr and Parr, 1978), whereas pinocytotic vesicles formed at the basal and lateral membranes were observed in the present study to move across the cell towards the luminal surface, where they may fuse with the apical cell membrane to release their contents into the uterine lumen by exocytosis. The latter observation suggests that there is intracellular transepithelial movement of materials from the blood and/or stroma into the uterine lumen. Since the direct passage of macromolecules between the intercellular spaces and the uterine lumen is blocked by the zonula occludens, or tight junction (Anderson et al., 1975), the intracellular pathway may account for the presence of macromolecules, such as plasma proteins, in the uterine fluid (Surani, 1977). One such protein is immunoglobulin $\mathrm{G}$ (IgG). Fluorescent-antibody labelling has localized $\mathrm{IgG}$ in the uterine stroma, along the basement membrane of the epithelial cells and in the luminal fluid (Tourville, Ogra, Lippes \& Tomasi, 1970; Symons \& Herbert, 1971). The mechanism of transfer from the stroma into the uterine lumen has not been elucidated. Symons \& Herbert (1971) reported that anti-IgG fluorescence was localized between epithelial cells but was absent from intracellular sites, and they inferred that IgG was transferred into the luminal fluids by an intercellular route. It is difficult to reconcile this suggestion with the known barrier function of the tight junction. There is also immunohistochemical evidence that immunoglobulin $\mathrm{A}(\operatorname{IgA})$ is transferred across the uterine epithelium into the luminal fluid. Secretory IgA has been localized in the uterine stroma, intercellular spaces of the epithelium, along the basement membrane, in the apical regions of the epithelial cells and in the uterine lumen in man (Kelly \& Fox, 1979), mouse (Bernard, Ripoche \& Bennett, 1977) and mare (Kenney \& Khaleel, 1975). Secretory component was also located in the IgA-containing epithelial cells (Poger \& Lamm, 1974). Uterine secretory IgA may be derived from serum polymeric IgA (Tomasi \& Bienenstock, 1968; Kelly \& Fox, 1979) or endocervix (Rebello, Green \& Fox, 1975). In the small intestine and mammary gland, there is extensive immunohistochemical evidence that IgA, secreted by plasma cells close to the basement membrane of the epithelial cells or derived from the serum, is taken into the epithelial cells, probably by a pinocytotic mechanism, is complexed with secretory component, transported across the cell and released into the luminal fluid (Tomasi \& Bienenstock, 1968; Brandtzaeg \& Baklien, 1977). Evidence obtained using immunoperoxidase labelling suggested that secretory component formed part of the basal and lateral membrane surfaces of the intestinal epithelial cells (Brown, Isobe \& Nakane, 1975; Huang, Fogh \& Hong, 1976) and could therefore be a membrane receptor for $\operatorname{IgA}$, facilitating its transport across the epithelium (Brandtzaeg \& Baklien, 1977). Several other systems for receptor-mediated endocytosis of proteins have been described (Goldstein, Anderson \& Brown, 1979). Selected extracellular proteins or peptides are first bound to specific cell surface receptors and then rapidly internalized by the cell. Internalization follows clustering of the receptors in coated pits that invaginate to form intracellular coated vesicles. For instance, maternal IgG enters fetal yolk sac epithelial cells via a membrane receptor specific for IgG and is transported intact in coated vesicles to the basal surface where IgG molecules are discharged into the fetal circulation (Schlamowitz, 1976). Extracellular proteins may also be transported non-selectively in non-coated pinocytic vesicles (Silverstein, Steinman \& Cohn, 1977). The pinocytotic activity at the lateral and basal surfaces of uterine epithelial cells on Days 5 and 6 involves both coated and non-coated vesicles, and may account for both specific and non-specific transport of macromolecules into the lumen. The transported macromolecules may be required for endometrial sterility (Kelly \& Fox, 1979), protection of the blastocyst against immunological rejection (Bernard et al., 1977), or blastocyst implantation and development (Gwatkin, 1969; Fishel \& Surani, 1978). 


\section{References}

Anderson, W., Kang, Y. \& De Sombre, E. (1975) Endogenous peroxidase: specific marker enzyme for tissue displaying growth dependency on estrogen. $J$. Cell Biol. 64, 668-681.

Bernard, O., Ripoche, M. \& Bennett, D. (1977) Distribution of maternal immunoglobins in the mouse uterus and embryo in the days after implantation. J. exp. Med. 145, 58-75.

Brandtzaeg, P. \& Baklien, K. (1977) Intestinal secretion of $\operatorname{IgA}$ and IgM: a hypothetical model. In Immunology of the Gut (CIBA Fnd Symp. No. 46 (new series)), pp. 77-113. Eds R. Porter \& J. Knight. Elsevier, Amsterdam.

Brown, W.R., Isobe, Y. \& Nakane, P.K. (1975) Ultrastructural localization of $\operatorname{IgA}$ and secretory component (SC) in human intestinal mucosa by immunoperoxidase techniques. Gastroenterology 68 , A-12/869.

Enders, A.C. \& Nelson, D.M. (1973) Pinocytotic activity of the uterus of the rat. Am.J.Anat. 138, 277-300.

Fishel, S.B, \& Surani, M.A.H. (1978) Changes in responsiveness of preimplantation mouse embryo to serum. J. Embryol. exp. Morph. 45, 295-301.

Goldstein, J.L., Anderson, R.G.W. \& Brown, M.S. (1979) Coated pits, coated vesicles, and receptormediated endocytosis. Nature, Lond. 279, 679-685.

Graham, R.C., Jr \& Karnovsky, M.J. (1966) The early stages of absorption of injected horseradish peroxidase in the proximal tubules of mouse kidney; ultrastructural cytochemistry by a new technique. $J$. Histochem. Cytochem. 14, 291-302.

Gwatkin, R.B.L. (1969) Nutritional requirements for post-blastocyst development in the mouse. Int. J. Fert. 14, 101-110.

Huang, S.W., Fogh, J. \& Hong, R. (1976) Synthesis of secretory component by colon cancer cells. Scand.J. Immun. 5, 263-268.

Karnovsky, M.J. (1971) Use of ferrocyanide-reduced osmium tetroxide in electron microscopy. Proc. 11th A. Meeting Am. Soc. Cell Biol. p. 284, Abstr.

Kelly, J.K. \& Fox, H. (1979) The local immunological defence system of the human endometrium. $J$. Reprod. Immun. 1, 39-45.

Kenney, R.M. \& Khaleel, S.A. (1975) Bacteriostatic activity of the mare uterus: a progress report on immunoglobulins. J. Reprod. Fert., Suppl. 23, 357358.

Leroy, F., Van Hoeck, J. \& Bogaert, C. (1976)
Hormonal control of pinocytosis in the uterine epithelium of the rat. J. Reprod. Fert. 47, 59-62.

Ljungkvist, I. (1971) Attachment reaction of rat uterine luminal epithelium. II. The effect of progesterone on the morphology of the uterine glands and the luminal epithelium of the spayed virgin rat. Acta Soc. Med. upsal. 76, 110-126.

Parr, M.B. \& Parr, E.L. (1974) Uterine luminal epithelium: protrusions mediated endocytosis, not apocrine secretion, in the rat. Biol. Reprod. 11, $220-233$.

Parr, M.B. \& Parr, E.L. (1977) Endocytosis in the uterine epithelium of the mouse. J. Reprod. Fert. $\mathbf{5 0}$, 151-153.

Parr, M.B. \& Parr, E.L. (1978) Uptake and fate of ferritin in the uterine epithelium of the rat during early pregnancy. J. Reprod. Fert. 52, 183-188.

Poger, M.E. \& Lamm, M.E. (1974) Localization of free and bound secretory component in human intestinal epithelial cells. $J$. exp. Med. 139, 629-642.

Rebello, R., Green, F.H.Y. \& Fox, H. (1975) A study of the secretory immune system of the female genital tract. Br. J. Obstet, Gynaec. 82, 812-816.

Schlamowitz, M. (1976) Membrane receptors in the specific transfer of immunoglobulins from mother to young. Immunological Commun. 5, 481-500.

Silverstein, S.C., Steinman, R.M. \& Cohn, Z.A. (1977) Endocytosis. Ann. Rev. Biochem. 46, 669-722.

Surani, M.A.H. (1977) Qualitative and quantitative examination of the proteins of rat uterine luminal fluid during pro-oestrus and pregnancy and comparison with those of serum. J. Reprod. Fert. 50, $281-287$.

Symons, D.B.A. \& Herbert, J. (1971) Incidence of immunoglobulins in fluids of the rabbit genital tracts and the distribution of $\mathrm{IgG}$-globulin in the tissues of the female tract. J. Reprod. Fert. 24, 55-62.

Tomasi, T.B. \& Bienenstock, J. (1968) Secretory immunoglobulins. Advances in Immunology 9, 1-69.

Tourville, D.R., Ogra, S.S., Lippes, J. \& Tomasi, T.B. (1970) The human female reproductive tract: immunohistulogical localization of $\gamma \mathrm{A}, \gamma \mathrm{B}, \gamma \mathrm{M}$ secretory "piece" and lactoferrin. Am. J. Obstet. Gynec. 108, 1102-1108.

Vokaer, E. (1952) Recherches histophysiologiques sur l'endomètre du rat, en particulier sur le conditionnement hormonal de ses propriëtes athrocytaires. Arch. Biol., Liege 63, 1-84. 